\title{
„ПОЗВОЛЕНИЯТ“ КУЛТУРЕН ОБМЕН МЕЖДУ НРБ И САЩ ПРЕЗ 60-ТЕ ГОДИНИ НА ХХ ВЕК
}

\author{
С. В. Самуилова
}

\begin{abstract}
Самуилова С. В. „Позволеният“ културен обмен между НРБ и САЩ през 60-те години на $\mathbf{X X}$ век. В статията се прави историческа реконструкция на контактите между Народна република България и Съединените американски щати в сферата на художествената култура след възстановяване на прекъснатите дипломатически отношения (1950-1959). Целта е да се очертае външната културна политика на НРБ спрямо Съединените щати през 60-те години на века и да се допълнят изследванията по темата за културното общуване на Народна република България със западните капиталистически държави през Студената война.
\end{abstract}

Ключови думи: културен обмен; Студената война; българо-американски отношения; култура.

Самуилова С. В. „Разрешенный“ культурный обмен между НРБ и США в 60-е годы $\mathbf{X X}$ века. В статье предпринята историческая реконструкция контактов Народной Республики Болгария и США в сфере художественной культуры после восстановления прерванных на десятилетие (1950-1959 гг.) дипломатических отношений. Статья призвана дополнить современную историографию культурной политики НРБ по отношению к США в 1960-е гг. и шире - к западным капиталистическим странам в период холодной войны.

Ключевые слова: культурный обмен; холодная война; болгаро-американские отношения; культура.

Samuilova $S$. $V$. The Allowed Cultural Exchange between the People's Republic of Bulgaria and the United States in the $60 \mathrm{~s}$ of the $20^{\text {th }}$ century. In the article is made a historical reconstruction of the contacts between the People's Republic of Bulgaria and the United States of America in the sphere of artistic culture after the restoration of the interrupted diplomatic relations (1950-1959). The aim is to be outlined the foreign cultural policy of PRB towards the United States in the 60s and to supplement studies in modern historiography on the cultural relations of the People's Republic of Bulgaria with the Western countries during the Cold War.

Keywords: cultural exchange; Cold War; Bulgarian-American relations; culture.

В българската историография началото на изследванията на културните контакти на Народна република България с капиталистическите държави след края на Втората световна война е поставено от Весела Чичовска. Авторката публикува няколко статии и една монография за международната културна дейност на страната през 1944-1948 г. ${ }^{1}$ Задълбочен анализ и продължаване на изследването в хронологически план от края на 50-те години до края на 60-те години прави Евгения Калинова в поредица публикации за културното общуване на НРБ с Франция, Италия, Англия и ФРГ². Авторката проучва и „културното отваряне“" на България през втората половина на 70-те години на XX в., ръководено от Людмила Живкова ${ }^{3}$. Историческата реконструкция на културните контакти със западноевропейските държавие в контраст с липсата на изследвания за културния обмен с лидера на западния свят в лицето на Съединените американски щати, койтоq макар и с ограничен обхват, представлява съществен елемент от българо-американските отношения през Студената война.

Културните контакти между българи и американци, макар и не много осезаеми, датират от началото на XIX в. благодарение на дейността на американските протестантски мисионери по българските земи - тогава част от Османската империя. След Освобождението българската културна общественост проявява силен интерес към Новия свят и неговата култура. Българите, макар и географски отдалечени, получават ясна представа за културните и научни постижения на Съединените щати. До 1947 г. в българската държава има постоянно присъствие на американска драматургия, филми, литература и образователни институции ${ }^{4}$. В края на 40 -те години културните отношения между България и капиталистическите държави, начело със САЩ, представляват реална заплаха за налагането 
и утвърждаването на комунистическата идеология. Културните контакти започват да се разглеждат като средство за пропаганда от двете страни на желязната завеса. Налага се принципът за недопускане на чуждото културно влияние и в същото време за прокараване на собствената култура ${ }^{5}$. След септември 1947 г. западната художествена култура е заклеймена като „упадъчна“ от съветската власт и заменена от т.нар. социалистически реализъм във всички форми на изкуството. По примера на Москва БРП(к), преименувана в края на 1948 г. в БКП, прекратява политиката на толериране на културните контакти сьс западноевропейските капиталистически държави и Съединените щати. Тази политика продължава до средата на 50-те години, когато външно- и вътрешнополитическите промени в САЩ и СССР оказват влияние за преосмисляне на решението за прекъсване на културно-образователните контакти между Запада и Изтока.

В желанието си за подновяване на културния диалог всяка от двете суперсили изхожда от различни подбуди и си поставя различни цели. В Съветския съюз смъртта на Сталин през 1953 г. оказва влияние за преориентиране на съветската външна политика. Новият лидер Никита Хрушчов и неговите поддържници вярват, че съотношението на силите се е променило в полза на социализма. Хрушчов демонстрира нараснало самочувствие през февруари 1956 г. по време на XX партиен конгрес, на който развенчава управлението на своя предшественик. Той обявява, че общата криза на капитализма продължава да се задълбочава, а позициите на империалистическите сили - да отслабват ${ }^{6}$. Тази убеденост налага преосмисляне на външната политика спрямо Запада. Новата стратегия е обявена като приемане на принципите на „мирното съвместно съществуване“" между държавите с различна политическа, икономическа и социална система. Формулирана като политика, целяща „намаляване на международното напрежение“, преосмислената съветска позиция се опитва да извлече максимум ползи от развитието на сътрудничество в различни области със Съединените щати ${ }^{7}$ с оглед придобиване на американските науки и технологии.

За САЩ подновяването на културните контакти с Източния блок показва прехода в политиката на Вашингтон от „освобождаване на пленените народи“ към „изграждане на мостове“. Налага се нов, по-умерен подход, разчитащ на еволюционните промени, които могат да се осъществят чрез „свободен поток на идеи“ с комунистическите държави. За разлика от началото на Студената война, когато всяка от двете суперсили се опитва да увеличава своето влияние, като не допуска влиянието на противника в своя ареал, стремежът за подновяване на сътрудничеството в определени области ги принуждава да разрешат ограничен обмен на културни ценности през желязната завеса. През октомври 1957 г. САЩ и СССР започват преговори за сключване на културно споразумение, подписано във Вашингтон в началото на следващата година. Договорьт става известен под името Лейси-Зарубин, наречен така по имената на главните преговарящи - представители на двете суперсили (посланикът на СССР в САЩ Георгий Зарубин и Уилям Лейси, помощник-държавен секретар на Съединените щати, отговарящ за източно-западните контакти). Съветският съюз не е първата държава от Източния блок, с която са подновени културните контакти, тъй като още в средата на 50-те години Полша и Югославия установяват сътрудничество с неправителствените фондации „Форд“ и „Рокфелер“ ${ }^{\text {“8 }}$, но единствено американско-съветският културен и образователен обмен има в края на 50-те години официален правителствен характер.

През 1951 г. ръководството на БКП за първи път обсъжда външната културна политика на държавата. По примера на СССР е създаден Комитет за приятелство и културни връзки с чужбина (КПКВЧ). Това е държавен орган, който централизира, контролира и направлява културната дейност зад граница, целяща пропагандиране на успехите на българския социализъм. Комитетът работи с чужди държави по подписани планове, съставени по предложение на българските дипломатически мисии зад граница и чуждестраннобългарските дружества. Плановете предвиждат размяна в областта на науката, културата, образованието, изкуствата, литературата и т.н. Разменят се културни дейци и колективи, художествени произведения, изложби, литература, филми, музейни и архивни материали. Устройват се дни, седмици и месеци на културата. Комитетът е обществен орган, което му позволява да работи заедно с всички видове обществени органи, творчески организации и институти в чужбина, чуждестранно-български дружества и частни лица. За тази цел той 
обединява по държавна линия дейността на българските институти, обществени организации и творчески съюзи, осъществяващи културни връзки с чужбина. КПКВЧ събира, обобщава и преценява данните за межународните културни връзки на България въз основа на културни споразумения, планове и протоколи. Тази своя дейност той извършва съвместно с Министерство на външните работи, Министерство на културата и Комитета по изкуство и култура, след което прави предложение пред Министерски съвет за подобряване и разширяване на културните връзки с чуждите държави. Той проучва и възможностите за създаване и разширяване на контактите с държави, с които няма сключени културни споразумения, планове и протоколи.

През 1957 г. НРБ приема принципите на мирното съвместно съществуване в основата на външната си политика. ЦК на БКП взема решение за разгръщане на широка кампания за рекламиране на постиженията на социалистическа България и за привличане на чуждестранни туристи, като тези дейности за първи път включват несоциалистически държави. Значението на културния обмен с развитите капиталистически страни се определя от интереса на българските власти към опознаване и използване на техните постижения в науката и техниката, както и към разширяване на стокообмена с тях. Това е началото на периода (1957-1969), който историкът и културолог проф. Иван Еленков определя „като етап на опит за частична либерализация на комунистическите подходи“, през който Тодор Живков налага едноличната си власт ${ }^{9}$. Подновяването на културния обмен върви със силни темпове. За 7 години КПКВЧ подписва културни споразумения с 28 несоциалистически държави ${ }^{10}$. В подготовката на плановете за културен обмен с тях Комитетът се съобразява с решението на Политбюро на ЦК на БКП „За по-нататъшното засилване на борбата срещу идеологическата диверсия на империализма“"11, като не позволява включването на прояви, които прокарват „вредни художествени и естетически концепции“.

При липсата на дипломатически отношения със Съединените щати КПКВЧ полага усилия за постепенно възстановяване на културните контакти на неправителствено ниво. Възстановени са прекъснатите връзки и са установени нови с американски неправителствени организации и частни лица. Чрез тях Комитетът се опитва да осъществи скромни мероприятия, целящи популяризирането на страната. Така например две фолклорни списания - „Roz in the Bow“ и „Вълтис“ от Калифорния - посвещават специални броеве на българските народни песни и танци, а списание „New World Review“ в продължение на 8 месеца публикува поредица статии за България. КПКВЧ работи за възстановяване на прекъснатите връзки с различни музеи (като Modern Art, Ню Йорк; Бруклински музей и др.), на които се изпращат албуми, монографии и рекламни материали. Музей от град Синсинати, щата Охайо, организира графична изложба с творби на български художници.

Комитетът влиза във връзка с различни обществени и културни дейци, много от които кани на посещение в страната. Сред гостувалите американци в края на 50-те години е известният художник и писател, председател на Съвета за американо-съветско приятелство (National Council of American-Soviet Friendship, NCASF) Рокуел Кент. По време на посещението му в България Кент отправя покана за организиране на графична изложба на българските творци Веселин Стайков и Васил Захариев. В края на 50-те години по покана на КПКВЧ в България пристига писателят, художник и публицист Артър Кан; кореспондентът на вестник „New York Times“ в Москва Харисън Солсбъри, който по време на посещението си през 1957 г. успява да вземе интервю с Тодор Живков. Между 1958 и 1960 г. българската държава е посетена от харлемските футболисти, артистите Пол и Френсис Ман и др.

В края на 50-те - началото на 60-те години развитие отбелязват контактите с редица американски музикални дейци и изпълнители. В България гостува диригентът на „Метрополитен опера“" Курт Адлер, който дирижира спектакли на Софийската и Варненската опера. През 1959 г. на посещение пристига американската оперна певица Бланш Тебом, на която са организирани две представления в Софийската опера („Кармен“ и „Аида“). По същото време концерти в България изнасят и американските певици Луиза Паркър, Франки Бакони и Марита Регулес.

За сметка на американските музикални изпълнители, до подновяването на дипломатическите отношения между САЩ и НРБ концерти в Америка има само един български изпълнител. Самостоятелно турне на собствени разноски и първо „проникване“ в САЩ след 
1944 г. осъществява прочутият оперен певец Димитьр Узунов. Гастрольт му е организиран от „Национална концертна и артистична корпорация““ (Ню Йорк) между октомври 1958 и април 1959 г. За този период Узунов изнася многобройни концерти в различни части на страната, включително и в „Метрополитен опера“.

Възстановяването на дипломатическите отношения между САЩ и НРБ през март 1959 г. поставя начало на официалните културни контакти. Тъй като двете страни нямат подписано културно споразумение, КПКВЧ работи на основата на свой едностранен план. Той включва изпращане на пропагандни материали на българската легация във Вашингтон, на отделни американски институции и частни лица, търсене на възможности за издаване на български книги и оказване на съдействие на американски граждани - посетители като туристи в България, с оглед „спечелването им“ за приятели и евентуалното им използване по-късно за популяризиране на страната. Протичането на културния обмен е затруднено не само по политически причини, но и по финансови. То се характеризира с многобройни предложения от американска страна и тяхното отхвърляне от българските власти. Българската държава отправя минимални предложения, тъй като не може да си позволи реципрочен обмен. Въз основа на писма и планове на КПКВЧ и Министерство на просветата, легацията във Вашингтон предлага осьществяване на няколко мероприятия, които да служат като основа за бъдещите преговори с американската държава. Пълномощният министър д-р Петър Вутов отправя предложение за популяризиране на българското музикално изпълнително и фолклорно изкуство чрез организиране на гастрол на Държавния ансамбъл за народни песни и танци, както и чрез изпращане на 2-3 от най-изявените оперни певци (Николай Гяуров, Димитър Узунов, Катя Попова и др.).

През 1961 г. българската легация предлага на властите в София подписване на културно споразумение със САЩ, което според нея ще е полезно при приемливи и за двете страни условия. Дипломатите провеждат два неофициални разговора с представители на Държавния департамент, които също демонстрират интерес към провеждане на преговори за уреждане на официален културен обмен. Засилването на политическото напрежение между двете суперсили в началото на 60-те години (Берлинската и Карибската криза) и смяната на президентската администрация във Вашингтон (идването на власт на президента Кенеди) оказват негативно влияние и върху българо-американския диалог, вследствие на което двете страни се отказват от подписването на културно споразумение.

През 1962 г. на посещение в страната пристига Франк Сиско, началник на Отдела за културен обмен със социалистическите държави към Държавния департамент. Той заявява пред председателя на КПКВЧ Екатерина Аврамова, че Съединените щати са заинтересовани от увеличаване на културния обмен, който според тях „спомага за създаване на миролюбива атмосфера в света“"12. Сиско уточнява, че мисията му не включва подписване на културно споразумение с България, а проучване на възможностите за разширяване на контактите в областта на културата. Той посочва в кои области американската държава има интерес за задълбочаване на сътрудничеството, а именно размяна на студенти, здравни работници, научно-технически делегации, уреждане на гостуване на известни български изпълнители в Съединените щати. Българската държава също проявява интерес към осъществяване на размяна на научни работници, което ще ѝ осигури легален достъп до американските науки и технологии. По тази причина тя приема предложението на американската неправителствена организация Междууниверситетски комитет за улеснение на пътуванията (МУУК) за размяна на учени и специалисти. През 1962 г. е подписано първото „Съглашение за размяна на дипломирани студенти и научни работници между висшите учебни заведения и научноизследователските институти в НРБ и САЩ за 1963-1966 г."13. Въпреки че обменната програма е с ограничен обхват, тя се подновява на всеки 2-3 години и продължава без прекъсване до края на Студената война.

За властите в София размяната на специалисти със Съединените щати представлява най-същественият дял от културния обмен между двете държави, докато „американската култура с упадъчните ѝ течения ..., не представлява интерес за нас като източник, от който можем да черпим опит“14. За разлика от тях, американската страна демонстрира по-голям интерес към разширяване на културните аспекти от обмена. В този смисъл трябва да се 
разглежда отправената покана от страна на Държавния департамент към българската държава за изпращане на културна делегация в САЩ на американски разноски за 6 седмици. Посещението е осъществено през 1963 г. от Борис Вапцаров, заместник-министьр на просветата и кулурата, и В. Илчев, началник на Отдела за културен обмен с капиталистическите държави към КПКВЧ.

Поради липсата на културно споразумение културната пропаганда на България в САЩ се осъществява главно по линия на българската дипломатическа мисия и от страна на единици заинтересовани американци. Чрез дипломатите във Вашингтон се организират изложби, прожекции на български филми, фотовитрини, информационни материали за страната и преведена на английски художествена литература. По-крупни мероприятия като гостувания на цели групи се извършват само на импресарски начала, поради големите разноски, с които е свързано изпращането на далечни разстояния. По такъв начин е уредено първото гостуване на български ансамбъл в САЩ след подновяване на дипломатическите отношения между двете държави. През 1961 г. Българска концертна дирекция съобщава, че е заинтересована от изпращането на гастроли в САЩ на изтъкнати български артисти и артистични групи. За тази цел Дирекцията влиза във връзка с Кърт Уейнголд, президент на „Колумбия артистс мениджмънт“. По време на посещението му в България той се запознава с няколко фолклорни формации. Преди отпътуването си от страната Уейнголд поема задължението да организира гостуването на Държавния ансамбъл за народни песни и танци в САЩ, от който „остава във възторг“15. Гастрольт на танцовата трупа в състав от 62 души се осъществява през 1963 г. и се радва на силен интерес от страна на американската публика. КПКВЧ е в контакт с друг импресарио - Ралф Паркър, който от своя страна се интересува от ангажиране на Николай Гяуров и на Младежкия симфоничен оркестър. За уреждане на гостуване в САЩ на ансамбъл или изпълнител българската легация влиза във връзка и води преговори с известните импресарии Хюрок и Вашегонов. Пак по импресарска линия е уредено и четиримесечно турне на младия български оперен певец Христо Радиев през 1961 г.

Класата на българската вокално-изпълнителна школа от 60-те години на века е представена пред американска публика от най-изявените оперни артисти на България в лицето на Николай Гяуров и Николай Бодуров (с представления в Чикагската опера) и на Райна Кабаиванска (в „Метрополитен опера“). За популяризиране на българското музикално изкуство в Съединените щати се оказва изключително успешно участието на българския диригент Месру Мехмедов в конкурса за млади диригенти „Дмитри Митропулис“. През 1969 г. той получава разрешение да се включи в традиционния международен музикален фестивал, провеждан ежегодно в Ню Йорк. С фантазията „Франческа ди Римини“ на Чайковски Мехмедов печели първо място в конкурса, председателстван от Ленард Бърнстейн. Като лауреат младият диригент получава покана за специализация в Нюйорската филхармония, осъществена през 1969-1970 г. През 1971 г. на връщане от Америка 35-годишният Мехмедов загива в самолетна катастрофа над Цюрих.

През втората половина на разглеждания период зачестяват контактите с музикалните среди на САЩ, чрез привличане на участието на американски изпълнителни дейци в български оперни и балетни конкурси като състезатели и членове на жури. През 1967 г. на Третия международен конкурс за млади оперни певци в София първа награда получава американката Джой Дейвидсън, която е удостоена и с втора награда за изпълнение на песен на български композитор. За член на журито е поканен Джон Браунли - директор на музикално училище в Манхатьн. През 1968 г. на Четвъртия международен балетен конкурс във Варна участват четирима души от САЩ. Младата американска балерина с български произход Ева Евдокимова е наградена с отличие в раздел „Младша възраст“. Мери Дей - директор на Вашингтонското балетно училище - участва като член на журито, което за първи път в историята на НРБ дава златен медал на американска гражданка, дъщеря на български политически емигрант. Това е първата голяма награда на бъдещата прима балерина, която получава в родината на своя баща.

През първата половина на 60-те години българските власти допускат няколко гастрола на американски ансамбли и отделни музикални изпълнители в България. През 1962 г. няколко представления изнася американски балет, а на следващата година Българска концертна дирекция организира на своя финансова издръжка концерти в София, Пловдив и 
Варна на известния пианист Юджийн Истомин. Между 1966-1969 г. мероприятия на американски музикални и вокални изпьлнители и ансамбли в НРБ не се организират изобщо. Причината за това се корени в новото засилване на напрежението между двата военно-политически лагера, провокирано от войната във Виетнам.

Сътрудничеството в областта на кинематографията заема съществено място в плановете на културния обмен на КПКВЧ. Властите в София са готови да допуснат размяна на „подходящи“ игрални, документални и научно-популярни филми на търговска база, създаване на постоянни връзки между американски филмови компании и Българска кинематография, уреждане на филмови премиери и размяна на филмови и телевизионни дейци. Американците от своя страна предлагат размяна на късометражни документални филми, но предимно туристически и то при условие, че „няма политика в тях“.

Във връзка с реализирането на плана за културната пропаганда в САЩ и популяризирането на България като първокласна туристистическа дестинация, българската легация организира коктейл в хотел „Лексингтън“ в Ню Йорк през 1961 г. съвместно с американската самолетна компания „КЛМ“. На него присъстват около 200 души, основно представители на различни туристически компании. Пред тях са прожектирани два документални туристически филма и са раздадени множество рекламни брошури. Според българските дипломати мероприятието преминава с „голям успех“. В отчетите си до Външно министерство те със задоволство отбелязват, че почти всички поканени гости присъстват на него.

Една от главните задачи на КПКВЧ е да заинтересува американски производители на телевизионни филми за заснемане на филм за България. През 1964 г. на посещение в страната пристига Робърт Роджерс, представител на фирма „Шеруин“ от Чикаго, който проявява интерес към заснемане на филм. В края на своето гостуване той подписва протокол за сътрудничество с Българската национална телевизия. През 1964 г. като гост на Комитета пристига Њрвинг Левин, директор на кинофестивала на Сан Франциско, който участва на кинофестивала във Варна. Поканата му е отправена с цел запознаването му с филмовото изкуство на НРБ и договаряне на участието на български филмови продукции в американски филмови фестивали.

Представянето на младата българска кинематография в Съединените щати и запознаването на американските кинодейци и публика с българските филми е задача, за която се полагат сериозни усилия. Въпреки това успехите са минимални, тъй като американските филмови разпространители не проявяват интерес към български филми. Най-крупното мероприятие, целящо популяризиране на българското филмово изкуство, е проведено в края на разглеждания период. През 1969 г. са организирани „Дни на българския филм“ в Ню Йорк. Българската държава изпраща делегация от филмови и телевизионни дейци, в която участва и известната актриса Невена Коканова.

За разлика от българското филмово изкуство, което не привлича интереса на американските филмови разпространители, то по българските екрани се прожектират по няколко филма на година от САЩ. Сред тях могат да се отбележат: „Царе на комедията“ (1963), „Великият Карузо“ (1963), „Старецът и морето“ (1963), „Да бъдеш или да не бъдеш“ (1965), „Кармен Джонс“ (1965), „Светьт на животните“ (1965), „Любов с един непознат“ (1965), „Певецьт от Нови Орлеан““ (1966), „Зорба Гъркът“ (1967), „Тези прекрасни мъже“ (1968), „Голата Маха“ (1968), „Кет Балу“ (1968), „Клеопатра“ (1968), „Обир в музея“ (1968), „Той се казваше Омбре“ (1968), ,Чудният свят на Братя Грим“ (1968), „Денят, в който рибите изплуваха“ (1968), „Познай кой ще дойде за вечеря“ (1969), „На учителя с любов“ (1969), „Укротяване на опърничавата“ (1969), „Д-р Фауст“ (1969), „Преследването“ (1969).

Контакти с американски театрални дейци за пропагандиране на постиженията в областта на театралното изкуство почти не съществуват през разглеждания период. Едно от редките посещения в тази област е осъществено през 1963 г. Тогава в България пристига Вирджиния Браун, представител на American National Theatre and Academy - организация с нестопанска цел за театрално образователно обучение. В качеството си на вицепрезидент по международния културен обмен на организацията тя се интересува от установяване на контакти с български театрални дейци.

През 60-те години на века българските постижения в областта на театралното изкуство остават непознати на американската публика. Единствената пиеса, която привли- 
ча интереса на западните критици, е „Прокурорьт“ на Георги Джагаров, играна през 1967 г. във Великобритания. През 1968 г. американското списание „The Nation“ публикува предговора към английското издание на пиесата с автор С. П. Сноу. В него пиесата е характеризирана като „най-директната атака срещу сталинизма, която е правена досега от източноевропейски писател“"16. В подробния анализ, заемащ 7 страници, се посочва, че интересът към пиесата на Запад е голям и много театри биха я поставили на сцените си ${ }^{17}$.

В същото време българската публика получава възможност да се запознае с класическата и съвременната американска драматургия. На сцената на държавните театри се играят пиеси, отразяващи живота на „гнилото“ буржоазно общество на съвременна Америка. За такава е приета постановката на Едуард Олби „Кой се страхува от Вирджиния Улф“, изпълнявана първоначално от югославска трупа. В есе за Едуард Олби, прочетено през 70-те години по Радио „Дойче Веле“, известният български драматург и дисидент Георги Марков отбелязва, че пиесата оказва „поразителен ефект“ върху българската публика в малкия театър „199“ на ул. „Раковски““ в София ${ }^{18}$. Интересът към представлението е толкова голям, че билетите са изкупувани с месеци напред ${ }^{19}$.

На сцената на държавните драматични театри през 60-те години на века се играят и едни най-известните пиеси на Артър Милър - „Смъртта на тьрговския пътник“, „След грехопадението“, „Поглед от моста“, „Цената“; сценарият на Ђрнест Леман „Уестсайдска история“, превърнат в музикален филм през 1961 г.; пиесата на Джон Патрик „Странната Мисис Сейвидж“, получила широка известност през 60-те години в Съветския съюз. Играят се още „За мишките и хората“ на Джон Стайнбек; „Машинописци“, „Тигър“ и „Любов“ на Мърей Шийзгал; „Орфей слиза в ада“, „Стъклената менажерия“ и „Трамвай желание“ на Тенеси Уилямс; „Митове от живота“ на Уилям Сароян; „Двама в люлката“ на Уилям Гибсън ${ }^{20}$.

Наред с произведенията на американската драматургия в българските балетни и оперетни театри се играят известни музикални пиеси като „Моята прекрасна лейди“ на Фредерик Лоу (в Пловдивската и Бургаската опера и в Дьржавния музикален театър в София през 1966-1967 г.), оперетата „Роз Мари“ от Фримъл (в Дьржавния музикален театьр през 1965-1966 г.), мюзикъльт „Целуни ме Кейт“ от Кол Портър (в Държавния музикален театър през 1965-1966 г.), мюзикълът „Уестсайдска история“" от Бърнстейн (в Пловдивската опера през 1967-1968 г.), „Рапсодия в синьо“ от Гершуин (като балетна постановка в Софийската и Пловдивската опера през 1967-1968 г. $)^{21}$.

За представяне на българската литература в Съединените щати се разчита преди всичко на преки контакти с американски литературни творци, издатели и разпространители. Въпреки че българската мисия във Вашингтон работи активно за установяване на връзки с американски издателства за превод и издаване на българска книга или отпечатване на статии, популяризиращи страната, дълго време успехи в тази област не са постигнати. Към средата на десетилетието са установени връзки с няколко американски издателства. С издателска къща „Туейн Пъблишърс“ от Ню Йорк се водят преговори за издаване на книгата на Иван Вазов „Под игото“. За тази цел през 1966 г. на двуседмично посещение в България пристига Якоб Стайнберг, представител на „Туейн Пъблишърс“, който преговаря с Издателството за литература на чужди езици и с Дирекция за защита на авторското право (книгата е издадена през 1971 г.). По същото време КПКВЧ подготвя антология с български разкази, която да послужи на издателство „Интернешънъл Пъблишърс“ за издаване на „Сборник с български разкази“. През 1964 г. издателство „Винтиж Прес“ публикува книгата на българската македонка, живуща в САЩ - Елена Борикова Крейвър, озаглавена „Български народни приказки“. На следващата година същото издателство публикува нейната втора книга, озаглавена „Коледни народни приказки“.

Докато българската литература остава напълно непозната в САЩ през 60-те години на века, то произведенията на американските класици (като Джек Лондон, Марк Твен, Едгар Алън По, Джеймс Фенимор Купър), а така също и на редица съвременни писатели (като Ђрскин Колдуел, Гор Видал, Ђптън Сенклер, Ђрвинг Стоун и др.) намират широк прием сред българския читател. Освен преведена американска литература, в НРБ са канени редица американски журналисти, драматурзи и писатели като гости на КПКВЧ с цел популяризиране на България в САЩ. Някои от тези посещения завършват с успех. 
В началото на 1965 г. в Съединените щати е издадена книгата „Bulgaria today - the land and the people“ от „Ехроsition Press“ Ню Йорк, дело на американския журналист Уилям Кари. За нейното написване Кари посещава няколко пъти България, където получава пълно съдействие от страна на Комитета. Не толкова успешно се оказва гостуването на американския новелист, журналист и деец на Комунистическата партия на САЩ Филип Боноски, който, въпреки че е приет на пълна издръжка на КПКВЧ с цел издаване на книга за България, в крайна сметка показва по-силен интерес към рекламирането на своите собствени книги.

Американските писатели Елмър Райс, Уилям Снодграс, Юрий Сцил и др. получават възможност за установяване на контакти с българските си колеги по време на ежегодно провежданите в София международни писателски срещи. На една тях, проведена през 1963 г., по покана на Съюза на писателите присъства известният публицист Ђрскин Колдуел. През 1964 г. като „посланик на изкуството“ в социалистическите държави пристига и един от най-големите американски писатели на XX век Джон Њпдайк. Една година след неговото посещение списание „Ню Йоркър“ публикува разказа му „Българската поетеса“, смятан за автобиографично произведение, описващо запознанството му с поетесата Блага Димитрова. Българският читател получава възможност да се докосне до едни от най-известните произведения на Колдуел и Ђпдайк благодарение на големия преводач от английски език Кръстан Дянков, поддържащ връзка и с двамата автори. През 1966 г. излиза преводът му на романа на Колдуел „Джени, жена по природа“, а през 1967 г. и преводът му на „Кентавърът“ на Ђпдайк.

Обменът в областта на художественото творчество е най-незначителен. Популяризирането на българското изобразително изкуство в Съединените щати е затруднено по две причини. На първо място, американските импресариа не проявяват интерес към българските художествени произведения, за които е характерен социалистическият реализъм. На второ място, изпращането и поддържането на голяма българска изложба в САЩ е твърде скъпо начинание от финансова гледна точка. Поради липсата на финансови средства остават неосьществени плановете за изпращане на изложбите „Красива България“ и на мащабната „2500 години изкуство по българските земи“, изложена през 1960 г. в Париж. Вместо тях д-р Петър Вутов предлага изпращане на изложби на българска графика на художниците Захариев и Стайков, но американците отхвърлят предложението. През 1963 г. Франк Сиско се интересува от възможностите за поставяне в САЩ на изложбата „Съкровищата на българските музеи“", която според него би представлявала интерес за американската публика. Председателят на КПКВЧ Екатерина Аврамова обаче отхвърля предложението. Тя отбелязва, че българската държава не желае да поеме транспорта и поддръжката на толкова мащабна изложба в Америка. През същата година завършва с неуспех и инициативата за поставяне на българска изложба в САЩ, отправена този път от мисията на НРБ във Вашингтон. Идеята ѝ включва организиране на богата витрина за България, която да бъде излагана в някои от големите американски университети с центрове за изучаване на славянски езици. Въпреки че българските дипломати установяват контакти със Славянските комитети на Колумбийския университет и университета Харвард, последните отхвърлят предложението за поставяне на такава витрина, изтьквайки факта, че в учебните заведения почти няма студенти, изучаващи български език.

В същото време някои от контактите на КПКВЧ с отделни американски институции се оказват по-успешни от инициативата на българската мисия във Вашингтон. Комитетьт изпраща общи материали, снимки и детски книжки за изложба на детска книга, организирана от библиотека в Уисконсин („Джоузеф Мен Лайбрьри“); албуми, книги и „битови““ кукли за изложбата „Култура и пътувания“, организирана от „Ривърс колеж“ в Балтимор; 15 художествени снимки за изложбата „Изкуството в религията“, организирана от университет в Колорадо, както и материали за изложба на българската култура, организирана в Харвард. През 1965 г. на легацията в САЩ е изпратена подвижната фотоизложба „България в снимки“, която може да се използва на различни места, където се провеждат вечери и сказки за България. През 1965 г. НРБ участва в изложба на социалистическите страни, организирана от Дьржавния университет на град Обърн, щата Алабама. Страната е представена чрез 30 книги, фоторепродукции на българска църковна дърворезба и фотоизложба на съвременна България. Последната, според ле- 
гационния секретар Петьр Василев, се радва на силен интерес от страна на различни училища. През 1969 г. в българското посолство в САЩ е уредена изложбата „Кирил и Методи“ по повод 24 май, а изложбата „Български пощенски марки“ е устроена в Сан Диего по случай 200-годишнината на Калифорнийския щат. За българската имиграция в Ню Йорк са уредени изложбите „Градини и паркове“ и „Строителството в България“, а фотоизложбите „Копривщица: град-музей“ и „Българските танци“ са устроени по време на фолклорен фестивал в Милуоки.

Българските власти трудно допускат провеждане на американски изложби на своя територия. Редките случаи, когато все пак са приети такива, то обикновено става за сметка на изпращане на български ансамбъл или изпълнител в Съединените щати. Така през лятото на 1963 г., докато се преговарят условията по организиране на турнето на Дьржавния ансамбъл за народни песни и танци в САЩ, е проведена за 3 седмици изложбата „Американски пластмаси“. Докато фотоизложби от Съединените щати все пак се допускат, макар и трудно, то произведения на американското изобразително изкуство не се приемат. Това се дължи на започнатото от Хрушчов и подето от Тодор Живков отричане на модернизма, абстракционизма и всичко, което не е подчинено на каноните на социалистическия реализъм в изобразителното изкуство.

Все пак съществува една област от българската култура, към която американците изпитват неподправен интерес. Българската дипломатическа мисия във Вашингтон получава многобройни запитвания от частни лица и неправителствени институции, интересуващи се от българския фолклор. КПКВЧ отбелязва, че „от САЩ повече, отколкото от всяка друга страна у нас пристигат на свои лични разноски много лица, които търсят помощта ни“⒉ Според Комитета този интерес е от полза за България, поради което е необходимо да се поддържат контакти с „тези ентусиасти и да се подпомагат, доколкото е възможно“23. За популяризирането на българския фолклор в Съединените щати през 1960-те години спомага допълнително гастрольт на Дьржавния ансамбъл за народни песни и танци, който получава добри отзиви за своето представяне в американската преса.

„Позволеният“ културен обмен между НРБ и САЩ се развива бавно и трудно през 60-те години на века. Върху него осезаемо влияние оказват както генерално отношенията между двете суперсили, така и политиката на БКП за недопускане на американско културно проникване в страната. Редките културни инициативи на Съединените щати, които се осъществяват през този период, се реализират след внимателна преценка за риска и за ползите, които може да извлече България от тях.

Българското културно представяне в САЩ е ограничено и случайно. При липсата на официално културно споразумение между двете държави НРБ е принудена да разчита найвече на връзки с частни лица. При това инициативата за провеждане на културни мероприятия често излиза от тяхна страна, но българската държава невинаги е в състояние да се възползва от предоставените ѝ възможности, главно поради лиспата на валута. За 60-те години на века са характерни многобройни покани до представители на американската култура, наука и общественост за гостуване в България, докато българските културни дейци, посетили Съединените щати, са единици.

Не може да се каже, че американската общественост се запознава с културните постижения на българската държава от случайно урежданите от импресарии отделни гостувания на състави или индивидуални изпълнители. Въпреки това някои американски среди получават представа за НРБ като страна с развита музикална култура.

Резултатите от културните връзки между Народна република България и Съединените американски щати показват, че през 60-те години на века най-широко представени пред американската общественост са българските постижения в областта на музикалното изпълнителско изкуство, а най-голям интерес се проявява към българския фолклор. За разлика от ограниченото българско културно присъствие в Съединените щати през разглеждания период, представянето на американските културни постижения в България е най-резултатно в областта на киното, литературата и театъра. Това е естествена последица от създадените културни традиции в културното общуване и в постоянния интерес на българската общественост към развитието на тези изкуства в САЩ. 
1 Чичовска В. Международна културна дейност на България 1944-1948. София 1990; Чичовска $B$. Културната политика на народнодемократичната власт 1944-1948 // Исторически преглед. 1979. № 4-5. C. 114-137; Chichovska V. Bulgaria’s international cultural relations (Sept. 9, 1944-1948) // Bulgarian Historical Review. 1975. No. PP. 3-27; Chichovska V. Bulgarian-British Cultural Relations. 19441948 // Bulgarian Historical Review. 1983. No. 1. PР. 22-40.

${ }^{2}$ Калинова Е. Европейските капиталистически страни в културната политика на България (втората половина на 50-те години) // Векове. 1988. № 3. С. 5-18; Калинова Е. Европейските капиталистически страни в сферата на международната културна дейност на България през втората половина на 50-те години // Годишник на Софийския университет „Св. Климент Охридски“. Исторически факултет. Т. 81. 1988. С. 5-57; Калинова E. „Разрешеният“ културен обмен на България със Западна Европа от средата н 50-те до средата на 60-те години // Лица на времето. Т. II. София, 1997. С. 239-266; Kalinova E. Bulgaria and the International Cultural Organizations (Mid-50s-Mid-60s) // Bulgarian Historical Review. 1991. Vol. 4. PP. 3-20.

${ }^{3}$ Калинова Е. Предпоставки и последици на културната политика на Людмила Живкова // Международни отношения. 2012. № 6. С. 61-70.

${ }^{4}$ Американските протестантски мисионери създават първите американски училища в българските земи още преди Освобождението. В началото на XX век в страната действат 22 мисионерски образователни институции с около хиляда ученика. През 30-те години на века Американският колеж в София се превръща в една от водещите чуждестранни учебни институции в България и място за обучение на децата на българския политически и културен елит.

${ }^{5}$ Калинова Е. Културни връзки между България и Франция след Втората световна война до края на 60-те години // Исторически преглед. 1999. Кн. 3-4. С. 117.

${ }^{6}$ Пеева П. Айзенхауер, Студената война и мирната алтернатива. Бургас, 2009. С. 175.

${ }^{7}$ Хрушчов Н. С. Отчетен доклад на Централния комитет на КПСС през ХХ конгрес на партията. София, 1956. С. 40.

${ }^{8}$ Richmond Y. Soviet-American Academic Exchange 1958-1975. Bloomington: Indiana University Press, 2001. P. 86.

${ }^{9}$ Келбечева E. Текстове за комунизма в България. Културната политика на България през времето на комунизма. URL: http://www.kas.de/wf/doc/kas_38762-1522-11-30.pdf?141127093152 (дата на посещение 16.08.2017).

${ }^{10}$ Централен държавен архив (по-нататък - ЦДА). Ф. 363. Оп. 9. А.е. 157. Л. 50.

${ }^{11}$ Пак там. Ф. 363. Оп. 8. А.е. 1396. Л. 5.

${ }^{12}$ Пак там. А.е. 334. Л. 97.

${ }^{13}$ Пак там. А.е 1648. Л. 70. Повече по темата: Самуилова $C$. „Пробиви в студената война: образователните обменни програми на САЩ във ФРГ и НРБ“. София: АИ „Проф. Марин Дринов“, 2017.

${ }^{14}$ ЦДА. Ф. 363. ОП. 8. А.е. 1102. Л. 3.

15 Дипломатически архив на Министерство на външните работи на Република България (по-нататък - АМВнР). Оп. 18. А.е. 287. Л. 4.

${ }^{16}$ Пак там. Оп. 25. А.е. 369. Л. 6.

${ }^{17}$ Пак там.

${ }^{18}$ Георги Марков за Едуард Олби. URL: http://kultura.bg/web/едуард-олби/ (дата на посещение 15.08.2017).

${ }^{19}$ Пак там.

${ }^{20}$ АМВнР. Оп. 25. А.е. 424. Л. 33.

${ }^{21}$ Пак там. Л. 32.

${ }^{22}$ ЦДА. Ф. 363. Оп. 8. А.е. 1084. Л. 17.

${ }^{23}$ Пак там. 